\title{
ESTUDIOS
}

\section{Os problemas da nacionalidade e originalidade da Literatura Brasileira}

$\mathrm{O}$ $S$ anos que se seguiram à abertura do romantismo no Brasil (1836) oferecem particular interêsse, pelo desenvolvimento, que se processou daí em diante, da consciência da nacionalidade literária, tanto entre os poetas e ficcionistas, quanto entre os críticos e teorizadores. Castro.

r. A Polêmica da Minerva Brasiliense: Abreu e Lima e Gama e

De excepcional importância, abrindo, por assim dizer, a questão, embora jamais haja sido antes bem examinado e pôsto no devido relêvo, é o debate em tôrno da "nacionalidade da literatura brasilieira" e de sua "originalidade", no qual tomaram parte alguns dos mais destacados publicistas da época.

A polêmica foi inaugurada por Santiago Nunes Ribeiro, na Minerva Brasiliense, um excelente e importante ensaio ainda hoje lido com proveito, provocado por afirmativas do General Abreu e Lima e do publicista português José da Gama e Castro. ${ }^{1}$

1 Oferecemos aqui alguns informes sôbre os contendores, colhidos nos dicionários de Inocêncio e Sacramento Blake.

José Inácio de Abreu e Lima (1795 ou 96-1869) nasceu em Recife, filho do famoso Padre Roma; de inteligência brilhante, recebeu educação esmerada, com os estudos de humanidades feitos em Pernambuco, e o curso militar na escola fundada no Rio de Janeiro, em 1810. Após o fuzilamento do Padre Roma envolvido na Revolução de 1817, o filho também foi prêso, conseguindo, no entanto, fugir e emigrar para os Estados Unidos. Depois, dirigiu-se para a Venezuela e a Colômbia, onde ofereceu setus serviços aos exércitos de Bolívar nas lutas pela independência contra Espanha. Batalhou com grande destaque, a ponto de atingir o pôsto de general, tendo sido objeto das maiores honrarias por parte das repúblicas da Venezuela, Colômbia, Peru e Bolívia. como verdadeiro herói militar. Percorreu, depois, a Europa, tetornando ao Brasil em 1832, a princípio residindo 
No Bosquejo (capítulo "Nosso estado intelectual; conclusão", p. 66), Abreu e Lima ao traçar um quadro do estado das ciências e letras no Brasil, procurara averiguar as raízes portuguêsas, pondo em contraste o que a metrópole espanhola fêz em relação às suas colônias americanas, para concluir pela inferioridade da cultura portuguêsa e pelo obscurantismo de sua colonização.

Em contraste com o ocorrido na América Espanhola, afirma ele "nunca pudemos obter uma Universidade no Brasil, nem ao menos que se nos ensinassem as Ciências exatas ou naturais"; acentúa que eta necessário ao brasileiro ir a Portugal para aprender. "Assim mesmo desgraçado do Brasileiro que se fazia notar pela sua inteligência ou por um gênio supetior; logo se lhe armava uma sancadilha, e o pobre homem era reduzido a uma prisão ou ao abandono da pátria". (p. 66).

Pelo estado de atraso cultural do Brasil, Abreu e Lima, com inspiração liberal e nacionalista, responsabiliza a má colonização portuguêsa e também idêntica situação de inferioridade intelectual que caracterizava a Metrópole.

Tampouco a Metrópole abundava de homens eruditos; (...) Existiam em verdade alguns homens, que mereciam com justo título a denominação de sábios; porém dêles não resta mais que uma memória estéril; se perguntarmos à Europa inteira que idéia faz da literatura portuguêsa, ela responderá que conhece a Camões e ao Abade Correia. Nos dirão talvez, que em algumas obras estrangeiras se encontram fragmentos de vários escritos portuguêses; porém isto deve considera-se como rasgos históricos de filologia e ciências de antiguidade. (p. 66).

no Rio de Janeiro e, após 1844, em Recife Entregou-se então a trabalhos intelectuais, sobretudo no campo da História. O livro de sua lavra que interessa ao problema aqui historiado é o Bosquejo bistórico, político e literário do Brasil (1835).

José da Gama e Castro, português de Coimbra, onde se diplomou em Medicina, por suas convicções miguelistas foi obrigado a emigrar, percorreu a Europa e fixou-se por fim no Brasil, aí vivendo entre 1837 e 1842 , dedicado ao jornalismo e a trabalhos literários. Além de traduçôes que publicou, colaborou no Jornal do Comércio, do Rio de Janeiro.

Santiago Nunes Ribeiro nasceu no Chile, e veio muito môço para o Brasil, forçado pelos acontecimentos políticos, acompanhado de um tio, seu. preceptor. Após a morte dêste, empregou-se no comércio, no interior do Rio de Janeiro; aproveitando para completar os estudos de humanidades, aprofundou-se sobretudo em letras e línguas vivas e mortas. Transferindo-se para a capital do Império, dedicon-se ao magistério particular e por fim ao oficial, no Colégio Pedro II, onde ccupou a cátedra de Retórica e Poética, e no Ateneu Fluminense onde ensinou Filasofia. Foi um dos fundadores e colaboradores e depois diretor da Minerva Brasiliense, importante periódico de 1843 a 1845 . Pertenceu ao Instituto Histórico e Geográfico Brasileito e ao Conservatótio Dramático, depois de 1845 . 
Adiante, insiste êle, caracterizando a sua crítica:

Se por literatura entendemos o Corpo de doutrinas que professa uma Nação, podemos assegurar, sem ser contestados, que os Portuguêses nunca possuíram nenhuma das ciências, que os literatos chamam de utilidade; porém se, para darmos um sentido, mais concreto à palavra, seguimos a classificação que fazem dos conhecimentos humanos e bibliográficos, então é mister confessar que os Portuguêses têm uma literatura que lhes é própria, e de algum modo original. (p. 67).

Iraça, então, um quadro sombrio e pessimista da evolução cultural portuguêsa, referindo os poucos nomes dos que se salientatam no passado, embora afirme que "os Fortuguêses nunca sobressaíram nas ciêncas de utilidade", pelo que, em parte, responsabiliza o clima de opressão e se admira "de que ainda pudesse achar-se em Portugal um homem que raciocinasse". Pergunta a essa altura: "Que se poderia esperar de uma Nação que corria com as ciências?" (p. 68).

Sua intenção ao por em relêvo tais deficiências não é, como êle mesmo o diz, "menoscabar o crédito de uma porção de homens", senão para que sua "lição nos sirva para corrigit-nos" (p. $7 x$ ) e para que "cuidemos ùnicamente em emendar a mão, educando os nossos filhos, e dirigindo-os pelo caminho das ciências e das artes". (p. 70).

Se existe alguma coisa de mais proveito, desejariamos sabê-lo; porque até agora temos feito um estudo particular da nossa literatura, e não podemos dar um passo mais adiante; chamamos-lhe nossa; porque ända ontem éramos Portuguêses (com quanto nos pese); e se rejeitarmos a literatura portuguêsa, ficaremos reduzidos a uma condição quase selvagem. Não sabemos porque fatalidade os Portuguêses ilustrados não se dedicavam a escrever, nem mesmo os Brasileiros, a exceção de algumas obras em poesia, ou alguma composição fastidiosa, uns e outros merecem igualmente o desprêzo em que eram tidos como literatos. (p. 69).

(...) Já agora temos de carregar com tôda a ignorîncia, que nos legaram nossos pais. (p. $7^{0}$ ).

Porém não devemos por isso entristecer-nos, visto que também tivemos alguns poetas. (p. $7^{\mathrm{I}}$ ). 
Reconhece que suas afirmações constituem uma "seta ervada, que vai ferir muito amor próprio exaltado" (p. 73), e apesar de saber que não escapará da pecha de detrator, insiste em que "contar-se-ão pelos dedos os sábios de todo o Brasil", tornando a repetir que "temos alguns homens, que honram a sua pátria como literatos, porém êles apenas constituem honrosas exceçōes em meio dessa turba empírica. (p. 73). Conclui então seu arrazoado em vários itens, de que se destacam os seguintes:

a) Que sendo nós outros descendentes dos Portuguêses, nos achamos por esta causa muito mais atrascidos em conhecimento que os nossos conterrâneos (os hispano-americanos), e somos por isso mesmo o Povo mais ignorante do Continente Americano;

b) Que sendo a nossa população composta de cinco distintas famílias, quatro das quais são inimigas e rivais umas das outras, não possumos verdadeiro carater nacional, o cual consiste na uniformidade de interesses, e bomogeneidade de todos os caracteres individuais. (p. 74).

Às teses do General Abreu e Lima sôbre as insuficiências da cultura brasileira em conseqüência de igual estado da portuguêsa, e ainda mais por causa da situação de colônia mal administrada, veio juntar-se mais tarde a opinião do publicista português, Gama e Castro, esta agora de outro ponto de vista. Ao anti-lusismo do brasileiro, responde com um anti-brasileirismo e um propósito de deprimir os brasileiros, defendendo a teoria de que as produções literárias dos brasileiros pertencem à literatura portuguêsa.

Gama e Castro colaborava no Jornal do Coméricio, entre r839 c 1842, quando deixou o Brasil; assinando-se "Um Português", em dois artigos, estuda os inventos portuguêses, no intuito de reivindicar para os portuguêses, numerosas invençōes que eram habitualmente atribuídas a filhos de outros países, e incluiu entre os portuguêses o brasileiro Bartolomeu de Gusmão.

Em carta ao jornal, um leitor que se assina "O Brasileiro", retifica a atribuição, declarando que, assim como "o comunicante portuguếs se queixa de tôdas essas usurpaçōes que afirma haverem sido feitas aos seus patrícios", os brasileiros tinham o direito de reclamar contra a tentativa de incluir os inventos do padre Bartolomeu de Gusmão entre as contribuições portuguêsas, desde que aquêle sábio, como seu irmão, nasceu em Santos, então vila de São Paulo. E, conclui, levantando uma questão importante: 
Porventura diremos nós que Cláudio Manuel da Costa, ou Frei Francisco de São Carlos são literatos portuguêses, ou que as obras de qualquer dêles pertencem à literatura portuguêsa?. Claro que não. Pois, se os escritos dêstes dois homeñs (por não estar a falar agora de outros muitos) fazem inconstetàvelmente parte da literatura brasileira, claro está que também os inventos do padre Bartolomeu Lourenço de Gusmão fazem parte dos inventos brasileiros.

A essa tese legitimista da literatura brasileira, que, pelo visto, era pacífica entre os brasileiros, a ponto de ser avançada tranqüilamente por um leitor comum sem a menor preocupação de se podia ser posta em dúvida, recebeu, todavia, de Gama e Castro a mais formal contradita.

Em outra correspondência, no mesmo jornal, responde êle ao "brasileiro" em tais termos e com tal acrimônia, que vale a pena uma transcrição mais ampla, a fim de se ter urna idéia nítida de sua posição e do debate a que deu lugar. ${ }^{2}$

Reconhece êle não haver dúvida quanto à naturalidade brasileira de Bartolomeu de Gusmão, mas que o problema não é êste, mas sim de que não havia diferença entre brasileiro e português antes da Independência.

Porém, quem não vê que no tempo em que nasceu e morreu Bar-. tolomeu de Gusmão ainda não havia, nem houve longo tempo depois, diferença de qualidade alguma entre Brasileiro e Português? Bastará porventura a localidade de nascimento de qualquer pessoa para se dizer que pertence a esta nação ou àquela? Neste caso, os filhos do embaixador da Rússia que aqui nasceram no Brasil ficarão sendo brasileiros. (P. x).

E passa então a censurar outra proposição, a relativa à literatura que o "Brasileiro" havia levantado, sem dúvida, sem imaginar que iria provocar qualquer controvérsia:

Diz êle que por Cláudio Manuel da Costa e Fr. Francisco de São Carlos serem brasileiros, os seus escritos fazem parte da literatura brasileira, e não da portuguêsa. Admitirei muito embora o princí-

2 Os artigos sôbre os "Inventos dos Portuguêses", foram estampados no Jornal do Comércio, Rio de Janeiro, 19 e 21 janeiro 1842; a carta do "Brasileiro", no mesmo jornal, de 24 janeiro 1842, e a resposta de "Um Português", a 29 janeiro 1842, sob o título de "Satisfação a um Escrupuloso". 
pio mas nego a conclusão. Fala-se de literatura brasileira por hábito, por vício, talvez por excesso de patriotismo; mas a verdade é que, em todo o rigor da palavra, literatura brasileira é uma entidade que não só não tem existência real, mas que até não pode ter existência possível. Esta proposição parece paradoxal; porém eu me explicando melhor, estou persuadido que todo o mundo ficarái tendo por axioma.

A literatura não toma o nome da tera, toma o nome da língua. Sempre assim foi desde o princípio do mundo, e sempre assim há de ser enquanto ele durar. Por ventura já alguém falou em literatura hanoveriana, em literatura austríaca, em literatura saxônia, em literatura bávara, ou em literatura prussiana, apesar de tôdas e cada uma destas literaturas se referirem a outras tantas nações tão soberanas e independentes como o Brasil? Não; é sempre a mesma literatura alemã, enquanto se trata de autores que escreveram nesta língua, e contudo Leibnitz era de Hannover, Kant, Copernico e Hermes (o teólogo) eram da Prússia, Schiller, Wieland, Herschell e K'epler, eram de Wurtemberg, Werner e Klopstock eram saxônios, Muller (o historiador) e Gessaner eram suiços.

Aduz em seguida, o exemplo italiano, o qual, afirma, the reforça $o$ argumento, pois, enquanto existe literatura italiana, não se pode falar em literatura toscana, lombarda ou napolitana. Apoia-se em citação de Antônio Dinis da Cruz e Silva, que sustentou a mesma idéia, num ditirambo a Jorge de Montemor, português que escreveu também em espanhol, e do qual disse Dinis:
Guarde lá sua Diana
Para a gente Castelhana:
Se falar em português
O brindará desta vez.

Continuando a sua argumentação em favor da tese de que a literatura tem o nome da língua em que se escreve e que, por isso, não hă: literatura brasileira e sim portuguêsa, enriquecida com as obras dos brasileiros, insiste:

Deus nos livre que a literatura fôsse mudando de nome com a dependência ou independência dos povos a que ela se refere. Se se admitisse tal absurdo, só agora é que começaria a existir literatura 
grega. Porque até aí teria sido literatura turca; e pela mesma razão, se algum dia a Inglaterra estivesse sujeita à França, acabada ficaria por êsse simples fato a existencia da literatura inglêsa. Porventura já alguém se lembra de dizer que as obras de Manzoni, de Monti, de Porta, de Romagnesi, de Goldoni, pertenecem à literatura austríaca, porque Milão e Veneza são hoje parte do império da Áustria, e não fazem como dantes, estados independentes? Certamente não: pertencem à literatura italiana, como até agora, e assim há de ser enquanto estiverem escritos na mesma lingua.

$O$ que aqui tenho dito, parece-me que é bastante para convencer; porém se tudo isto não é ainda suficiente, eis aqui mais um argumento que serve de contra-prova, e que me parece sem réplica. Cuvier era alemão, porque nasceu em Montelliard, no reino de Wurtemberg, e contudo as suas obras pertencem à literatura francesa porque, escreveu em França; e, pelo contrário, Ancillon era francês porque nasceu Estrasburgo, e as suas obras pertencem ì literatura alemã, porque as escreveu nessa língua.

O mesmo se deve dizer das obras de Silvestre Pinheiro Ferreira, que incontestàvelmente fazem parte da literatura francesa, apesar de êle ser português.

A única exceção (a muito apertar) desta regra seria quando as obras fôssem escritas em línguas mortas, e que jái não são de povo nenhum; porque, neste caso, talvez se possam, com alguma aparência de razão, classificar na literatura daquela língua a que pertence o autor que as escreveu. Por esta regra talvez possamos classificar na literatura portuguêsa as obras de D. Jetônimo Osório, bispo de Silvos, apesar de serem escritas de rebus Emmanuelis, em tão bom latim como o de Tito Lívio; talvez possamos fazer o mesmo com os epigramas latinos do padre Reis, que ombreiam com os de Marcial; talvez o mesmo possa dizer-se dos escritos daquele tão célebre como desgraçado bispo de Évora, D. Garcia de Meneses, que de tal modo falou latim em Roma, perante o Sacro Colégio, que um dos cardeais perguntou espantado ao seu vizinho: Quis est iste barbarus, qui tan latino lequitur? Porém isto mesmo me parece caprichoso e afetado.

E, então, resume o publicista luso o seu arrazoado no seguinte axioma: 
Não há portanto literatura brasileira, assim como não há literatura argentina, literatura boliviana, ou literatura mexicana: agora o que certíssimo há é que em muitas obras escritas por brasileiros consiste um dos principais ornamentos da literatura portuguêsa. Tais são os escrtios do padre Caldas; tal é o Caramuru de Fr. José de Santa Rita Durão; tais são as obras de Vicente José Ferreira Cardoso, que todo o mundo trata por Português, e que nasceu na Bahia; tal é sobretudo o poema de sacchari opificio, escrito por Fr. Prudêncio do Amaral.

E nisto é que provàvelmente vai o engano: a literatura é portuguêsa. Se alguém, falando do dr. Visconde de S. Leopoldo, disser o literato riograndense; se, falando do Visconde de Cairu, disser o literato baiano; se, falando do sr. bispo capelão-mor, disser o literato pernambucano, nenhum obstáculo the ponho: porém, se me vierem falar de literatura pernambucana, de literatura riograndense, ou de literatura baiana, recebo-os com assobios. E seja isto dito, salivo meliori judicio.

Em resumo, pode-se consubstanciar a argumentação de Gama e Castro em algumas proposições: I) Para que existisse uma literatura brasileira, preciso era que estivesse consignada noutra língua que não na portuguêsa; 2) Um autor que escreve num idioma que não no do seu país natal passa a pertenecer à história dêsse idioma; 3) Se os que têm uma pátria e língua sua passam ao domínio literário de outros povos pelo fato de escreverem na lingua estranha, como hão de pertencer a literaturas diferentes os que desde o berço falam o mesmo idioma e nêle escrevem, só porque nasceram em diversas circunscriçōes territoriais? 4) Afastados ou limítrofes, os povos que falam um mesmo idioma confundem as suas inspirações num pensamento idêntico e são conhecidos no mundo das artes e das ciências por um só nome de família; 5) Os literatos são brasileiros, porém a literatura que êles escrevem é portuguêsa; 6) A literatura não pode mudar de nome com a dependência ou independência dos povos a que ela se refere; 7) A literatura não toma o nome da terra, toma o nome da língua; 8) Fala-se de literatura brasileira por hábito, por vício, talvez por excesso de patriotismo, mas a verdade é que literatura brasileira é uma entidade que não só não tem existência real, mas que até não pode ter existência possível.

O relêvo que emprestamos a essa posição justifica-se pelo fato de que ela representa a teoria portuguêsa, que veio de Garrett e se prolonga por tôda a historiografia literária lusa. 
No caso presente, estamos perante a concepção extremista, segundo a qual é negada a própria existência da literatura brasileira, porquanto, sendo escrita no idioma luso, a produção brasileira deve pertencer à literatura portuguêsa.

Mas há, nessa posição portuguêsa, a tese moderada, segundo a qual a literatura que se produz no Brasil é reconhecida como brasileira apenas na parte posterior à Independência. Essa tese faz depender a nacionalidade em literatura da existência de estados-nações, independentes, como se não houvesse inúmeras literaturas com existencia anterior à unidade nacional e à autonomia dos países sob forma de estados nacionais, tais como a italiana, a alemã, etc.

E uma teoria evidentemente de sentido político, subordinando a existência da literatura ao fenômeno político, e dela decorre tôda uma linha de historiografia, com a periodização correspondente, que divide a literatura brasileira em duas fases - a colonial e a nacional.

2. Santiago Nunes Ribeiro.

A reação contra essa teoria partiu primeiramente de Santiago Nunes Ribeiro. No primeiro número da Minerva Brasiliense, assumiu corajosamente atitude de combate frontal às idéias do publicista português, com um estudo intitulado "Da Nacionalidade da Literatura Brasileira"."

O fato de o importante ensaio de Santiago Nunes Ribeiro, co-fundador e colaborador do periódico, ser publicado abrindo o número de lançamento do periódico, é indício de que lhe dava o caráter de uma espécie de manifesto de um grupo de escritores, naquele momento crucial do início do Romantismo, em que se reuniam as fôrças intelectuais em tôrno da idéia da nacionalidade da literatura brasileira, e de sua expressão autônoma e original. E o curioso é que, ao lado do Cônego Januário da Cunha Barbosa, Joaquim Norberto de Sousa e Silva, Gonçalves de Magalhães, José de Alencar, Gonçalves Dias, Araújo Pôrto-Alegre e outros grandes espíritos brasileiros, se colocasse também um estrangeiro de: origem, embora havia muito radicado no Brasil, que revelava tão aguda sensibilidade para o problema, sôbre êle refletindo de maneira magistral, ainda hoje digno de aprovação, pelo bom senso, cultura e segurança doutrinária.

Começa êle perguntando:

O Brasil tem uma literatura própria e nacional, ou as produções dos autores brasileiros pertencem à literatura portuguêsa, já em

3 Minerva Brasiliense, I, 1, Rio de Janeiro, 1-11-1843, pp. 7-23. 
virtude dos vínculos que uniam ambos os países, já em consequência de serem escritos na língua lusitana? (p. 8).

Essa é a questão fundamental que resume tôdas as teses dos que discutiram o assunto até aqui. Com absoluta lógica no desenvolvimento de seus raciocínios e argumentos, estabelece algumas premissas teóricas, como a de que as épocas se distinguem por um pensamento comum e dominante, advindo das crenças e idéias que os livros e doutrinas perpetuam, as quais vão desaparecendo ou assumem um caráter hostil à medida que um novo pensamento as absorve ou as repele. $\mathrm{E}$ o conceito moderno segundo o qual os periodos se caracterizam por um conjunto de normas filosóficas, estéticas e estilísticas que regulam a ideologia e a composição das obras de arte.

Passa em seguida a "prevenir as objeções, ou antes por destruir os preconceitos que a opinião infensa às letras brasileiras pode ter suscitado nos leitores", e combate as idéias de Abreu e Lima. Pensa que o autor do Bosquejo, ao afiançar que "se rejeitarmos a literatura portuguêsa ficaremos reduzidos a uma condição quase selvagem", funda-se num engano acêrca da natureza e constituição da literatura pròpriamente dita. Ao parecer de Abreu e Lima, literatura é o corpo de doutrinas que professa uma nação, mais especificadamente, como diz Nunes Ribeiro, "o essencial numa literatura consiste na cópia, variedade e originalidade de obras relativas às ciências exatas, expirimentais e positivas; e que a poesia, eloqüência, a história apenas são apêndices de pouca monta", como prova a insistência do autor em apontar "a penúria de obras portuguêsas e brasileiras sôbre as referidas ciências".

Reconhece uma acepção lata para a literatura, que "significa a totalidade dos escritos literários e científicos", e por isso dizemos literatura teológica, médica, etc., mas isso não nos deve levar a admitir tal acepção quando se trata da literatura própriamente dita. "Ninguém ainda procurou a literatura italiana, inglesa ou francesa nas Memórias da Academia del Cimento, nas Transaçōes filosóficas, ou no Journal del Savans ou de Physique". (p. 8).

$O$ alvo mais particularmente visado pelo ensaio é o artigo que enfeixa as teorias de Gama e Castro, contra o qual se desenvolve o mais da argumentação que apresenta:

Não é o princípio incontestável que a divisão das literaturas deva ser feita invariàvelmente segundo as línguas, em que se acham consignadas. Outra divisão talvez mais filosófica seria a que aten. 
desse ao espírito, que anima, à idéia que preside aos trabalhos intelectuais de um povo, isto é, de um sistema, de um centro, de um foco de vida social. Este princípio literário e artístico é o resultado das influências, do sentimento, das crenças, dos costumes e hábitos peculiares a um certo número de homens, que estão em certas e determinadas relações, e que podem ser muito diferentes entre alguns povos, embora falem a mesma língua. (p. 9).

Continuando, mostra como, aléms daqueles fatores, é mister levar em conta a influência do meio social e do clima, de conformidade com o pensamento de Hipócrates, Buffon e Montesquieu, o qual, mais tarde, Taine codificaria na sua famosa lei determinista da influência do meio, raça e momento. Assim se expressa Nunes Ribeiro:

As condições sociais e o clima do novo mundo necessàriamente devem modificar as obras nêle escritas nesta ou naquela língua da velha Europa. Quando vemos que o organismo dos seres vivos não pode subtrair-se à ação dessas causas naturais, como não admitir que as faculdades mais nobres participam da ação dessa influência e que os produtos da inteligência devem ressentir-se dela? (p. q).

Depois de admitir a realidade dessa influência, que, afirma, "a escola histórica de Hegel tem pôsto (...) na sua luz verdadeira", mostra como a natureza brasileira, com suas grandiosidades e primores, não pode deixar de influir poderosamente sôbre os artistas, um país onde "o belo fenomenal se mostra com a maior pompa neste céu afortunado", de modo que os artistas "beberam nele a inspiração mais pura, a inspiração criadora de obras excelentes, revestidas de vivas côres, de donosas formas, idealizadas nas harmonias da arte musical e poética".

Agora perguntaremos se um país, cuja posição geográfica e constituição geognóstica, cujas instituições, costumes e hábitos tanto diferem dos da sua metrópole de outrora, não deve ter sua índole especial, seu modo próprio de sentir conceber, dimanante destas diversas causas, modificadas umas pelas outras; se, numa palavra, não deve ter caráter nacional. Sim, nos dirá todo aquêle que estiver desprevenido. A literatura é a expressão da índole, do caráter, da inteligência social de um povo ou de uma época. (...) Ora, se os 
brasileiros têm seu caráter nacional, também devem possuir uma literatura pátria. (p. ro).

Alicerçado em citação de Chateaubriand, mostra em seguida a semrazão da identificação da língua e literatura, mostrando como são diferentes entre si as quatro literaturas que usam a língua inglêsa: a irlandesa, a inglêsa pròpriamente dita, a escocesa e a americana salientando as peculiaridades da irlandesa em relação à inglêsa.

Se pois nas línguas européias há diferenças tadicais de estilo e de maneira, isto é, se numa língua mesma, falada por povos que estão debaixo do mesmo céu, a pesquenas distâncias e com relaçôes já seculares, há literaturas diferentes, por que não se há de permitir que as de povos que habitam a duas e três mil léguas de distância, e cujos costumes, leis e usanças longe estão de ser perfeitamente idênticos, tomem a denominação de sua própria nacionalidade? (p. II).

Ninguém nega, comenta adiante, o direito de os Estados Unidos afirmarem que têm uma literatura, e ninguém se dirigirá aos americanos nestes têrmos: "Vós não tendes literatura, por isso que falais inglês; a que abusivamente apelidais vossa, é parte integrante da britânica", e isso, a despeito da humildade com que os americanos, até I820, não aspiravam, como afirma, a ter uma literatura.

O mesmo ocorre com o México, pois ninguém dirá que as suas produções literárias pertencem "ao fundo inalienável da literatura hispânica". Ao contrário, o México tem una literatura própria. ${ }^{4}$

Em resumo, ao seu juízo, a classificação das literaturas deve ser feita "não em relação às línguas, mas com respeito ao princípio íntimo que as anima, e às tendências que as distinguem", para o que se torna necessário identificar os predicamentos peculiares e os traços característicos que as diferençãm entre sí, no caso, a literatura brasileira da portuguêsa.

Seu trabalho desenvolve então três pontos: uma réplica à tese da imitação da literatura brasileira; um paralelo entre os pontos portuguêses e brasileiros; e uma tentativa de periodização da literatura brasileira.

A identidade da lingua e dos estudos nos dois povos deveria ser um fator que desse "à poesia brasileira o caráter e feições da portuguêsa". Entretanto, outras causas não menos poderosas atuaram de modo contrário. E, em oposição a Denis e Garrett, pensa êle que a poesia brasileira an-

4. Sem conhecimento dessa afirmação, defendi tese semelhante em Conceito da Literatura Brasileint, p. 66. 
terior à Independência teve a sua peculiaridade nacional, mesmo quando se veste à grega ou à romana, e procura provar a assertiva.

Basela-se num princípio muito sábio de teoria literária, segundo o qual não é lícito exigir do poeta "compreender ou representar o belo de outro modo que não daquele que a sua época e tendências individuais exigiam", pois "quando não se atende ao caráter de cada uma das fases literárias, a cada uma das modificações que a arte recebe das causas interiores e exteriores, não se faz justiça aos homens destą ou daquela época, só porque nêles vemos o que chamamos defeitos. (P. I2). Combate êsse tipo de crítica estreita de fundo neoclásico, pois só quando foi abolida é que se compreenderam diversos gênios literários de outros tempos, como Homero, Dante ou Shakespeare.

Segundo essa perspectiva crítica, julga que a poesia brasileira da época anterior à Independência foi o que devia ser, porquanto "a disposição dos espíritos não permitia que a natureza fôsse encarada sob o aspecto que hoje nos agrada tanto, e que não é lícito exigir de um século aquilo que êle não pode dar". (P. I2). E acrescenta: os poetas brasileiros dos tempos colonias "não poderiam contemplar a natureza como os nossos poetas, nem pintá-la com as mesmas côres, e se isto fôsse possível a sociedade os não entenderia, até que certas idéias lhes fossem abrindo novos horizontes". ( $p .13$ ). Cita Cláudio Manuel da Costa quando confessa que, ao regressar à pátria, só enxergava "a grosseria dos seus gênios", o que naturalmente o leva "ao ócio e à ignorância", e pela "desconsolação de não poder substabelecer aqui as delícias do Tejo, do Lima e do Mondego", teve entorpecido "o engenho dentro de meu bêrço". (p. (13).

Assim, a um poeta que não sentia nem apreciava a natureza que $o$ cercava e que deplorava "a falta dos primores de outro clima", não "se devia esperar a descrição de objetos que êle repita prosaicos e contrários à inspiração".

Que the importam as palmeiras a êle que não vê o álamo copado nem as venturosas praias da Arcádia? Não podia pois êste poeta pintar o que para êle não era poético. Pouco tempo depois os novos livros, a gradual transformação do gôsto, de hispânico-italiano que era, em trancês alatinado, produziram uma reação favorável a poesia descritiva. Mas esta reação não devia ser tal como os críticos parecem desejar que houvesse sido. Ainda outra vez: não podia ser senão o que foi pela fôrça mesma das idéias. - Mas podiam ter pintado as cenas da natureza americana. - Não podiam fazê-lo. (p. I3). 
E a resposta que opõe ao pensamento de Denis e Garrett: sobretudo o último, para quem os poetas brasileiros deveriam empregar a côr local ganhando assim maior vivacidade e americanidade. Sua teoria combina-se com a máxima de Cousin, de que "a ninguém é dado caminhar adiante do seu século".

Procura-se arguir a poesia anterior à Independência de pouco brasileira em virtude do seu uso da mitologia, pela sua carência de côr local e por ser iniciativa. No entanto, se válida fôsse tal crítica, dela não escapariam muitos dos poetas que, depois, se entregaram à exaltação da natureza exterior, ao misticismo, ao orientalismo, sob o impulso romântico, mas ainda usavam a mitologia, as comparações e imagens clássicas, como Garrett, Castilho e o próprio Gonçalves de Magalhães.

Quanto ao cunho imitativo da literatura brasileira em relação à portuguêsa, se por imitação se deve entender as influências de umas sôbre outras literaturas, é evidente que nenhum se eximiria dessa pecha. E aponta a influência espanhola na literatura francesa do século XVII, a qual foi cedendo o passo à grega e à romana, e depois à inglêsa. Por outro lado, a literatura inglêsa do Renascimento imitou a italiana. Relativamente à portuguêsa, no século xvin não se isentam da pecha Bocage, Garção e outros, todos imitadores dos romanos, especialmente Horácio. "A vista do que deixamos expendido não é uma injustiça articular tal acusação contra os poetas brasileiros porque foram arrebatados pela corrente, porque obedeceram a uma lei universal?" (p. Is). Essa injustiça estende-se a uma pléiade notável de poetas, os árcades brasileiros, Cláudio, Durão, Basílio, os Alvarengas, Gonzaga, Caldas, S. Carlos.

Não se deveria antes louvar a moderação com que imitam e sobretudo as novas direções que tomam no que se nota originalidade e uma aspiração que os poetas portuguêses não tinham? Mas a injustiça desta censura que se lhes faz de imitadores sobe de ponto quando se acrescenta que a são dos portuguêses: Que! os poetas brasileiros não tinham diante dos olhos outros exemplares? Conheciam as literaturas estrangeiras só pelos transuntos portuguêses? Se copiavam não era dos mesmos originais que os portuguêses consultavam? Cumpre dizê-lo, visto que já tocamos neste segundo ponto que nos tínhamos proposto de tratar, isto é os especiais méritos dos poetas brasileiros, embora nos arrisquemos a repetir alguma coisa. Não queremos deprimir homens de tanto mérito como Garção, Dinis, Francisco Manuel, etc., mas preencher um dever da crítica, a quem incumbedeterminar o grau e natureza da instrução dos homens célebres, com- 
pará-los sob êste ponto de vista, porque desta maneira se pode fazer justiça a cada um dêles e explicar o que nas suas obras parece inexplicável. Cumpre pois lançar mão dêste expediente pois que os queremos comparar como o exige o nosso caso. Pouca instrução tinham os poetas lusitanos que citamos, como das suas obras se depreende. Se no latim eram algum tanto lidos, escasa notícia tinham das línguas vivas e do grego. (P. I5).

Compara então a cultura dos poetas portuguêses e brasileiros, apontando a superioridade de muitos brasileiros, como os padres Caldas e S. Carlos, Cláudio e os Alvarengas, versados em latim, grego, italiano, trancês e espanhol, sem fazer em Basílio e Durão muito instruídos, e sobtetudo no sábio José Bonifácio.

Fica, segundo nos parece, provado com os fatos que os brasileiros não estavam reduzidos a reproduzir as imitações portuguêsas, que não era através dos escritos da mãe pátria que êles viam o que de melhor havia sido publicado, que bebiam nas fontes, recebiam a luz e não o reflexo. (p. I6).

Não se deve, portanto, procurar afora do Brasil a fonte inspiradora dos poetas que aí nasceram e viveram.

A poesia do Brasil é filha da inspiração americana (...) o gênio dos brasileiros pertence ao clima, ao solo, ao Brasil finalmente. Assim em vez de considerar a poesia do Brasil como uma bela estrangeira, uma virgem da terra helênica, transportada às regiões lo novo mundo, nós diremos que ela é filha das florestas, educada na velha Europa, onde a sua inspiração nativa se desenvolveu com o estudo e a contemplação de ciência e natureza estranha. (p. I6).

Vários poetas brasileiros correram mundo, nenhum porém se desligou da pátria, ao contrário sua imaginação viveu presa às mil seduções do clima e da paisagem locais, como testemunha o poema "As Aves" de Caldas:

Nos climas do Brasil onde amor vive

Dos esquisitos deleitos, de finezas,

E de ternas meiguices rodeado. 
Não será, pois, sem propósito afirmar da musa brasileira que "se ela se lembrou tanto do Brasil é porque o tinha por sua pátria e assim experimentava o sentimento da sua nacionalidade", ( $p . I_{7}$ ) daí o enveredar por caminho próprio, diverso da portuguêsa (que, por vêzes, passa a imitá-la), vitoriosa com sua sua côr local na lírica, no gênero descritivo, nos cantos amorosos.

Assim detendida a nacionalidade da poesia brasileira, cabe estudar a sua origem e achar a sua carcterística, o que constitui a última parte do seu ensaio.

$\mathrm{O}$ início da literatura brasileira está intimamente ligado à religião, que torneceu os alicerces da civilização nascente. "Que poesia nas mãos da religião foi um instrumento de civilizaçào é incontestável" (p. Iq).

Situa a figura do padre Anchieta como o fundador da poesia brasileira. Ê que êle "ensinava em verso como os legisladores e moralistas da antiguidade. Os primeiros ensaios de poesia dramática lhe são devidos". (p. Iq).

Não sòmente pela sua própria contribuição pessoal, através da poesia lírica e dos autos, mas também pela sua ação evangelizadora incutindo nos selvícolas as noçōes básicas da moral, os princípios do bem e do mal, as noções do pecado e da pena, Anchieta criou na gente primitiva e na sociedade incipiente um estado de espírito em que dominavam os valores cristãos e o sentimento religioso, logo manifestado no folclore.

A poesia popular o revelava por toda a parte, ela que é a expressão mais fiel das crenças e dos sentimentos de um povo. (p. I9).

E de singular importância a observação que faz da influência de Anchieta na formação da poesia popular, mais un argumento a colocá-lo como o fundador da literatura brasileira.

O sentimento religioso e o elemento descritivo dão-se as mãos na poesia brasileira, e aos poucos vão dominando como suas características: "A piedade cristã, o amor da natureza, a admiração das ações heróicas, formaram o caráter da musa do Brasil", que, se "pelas suas qualidades positivas (...) leva grande vantagem à portuguêsa pelas negativas também podemos conhecer algum mérito nela". (p. 2I).

Até na escolha das espécies de versos os poetas brasileiros mostraram seu gênio inovador e a inquietação interna que os fazia experimentar novas combinações. O regime político já era mal aceito, e o regime literário foi seguindo a mesma sorte. (P. 2I). 
Assim, assinala o desapreço pelo ditirambo entre os brasileiros, contràriamente aos portuguêses, por outro lado cultores das cantadas e odes em versos soltos.

Mas o Padre Caldas pressentiu o gôsto do século, abandonou, em muitas de suas composições, a versificação sôlta que tão recomendada tinha sido por Garção, e seguida tão à risca por Filinto. Ponco depois devia Lord Byron rejeitar o verso sôlto que Milton e Thompson preferiram. A revolução foi geral. Ao mesmo passo que na França se apresentavam teorias e tentativas de verso sôlto, as nações que têm línguas sonoras, acentuadas, adotavam a rima, nas composições líricas. (pp. 2I-22).

E realmente de admirar a lucidez e argúcia crítica, além da segurança de juízo, revelado por Nunes Ribeiro, se quisermos colocar-nos em seu tempo para avaliá-lo.

Há ainda outro ponto que assinala, para mostrar a superioridade do gênio poético brasileiro. En quanto o vate brasileiro se inclinava para as tendências românticas da poesia rimada, poetas lusitanos havia fiéis ao talho grego e romano, "de maneira que ao tempo em que o gênio brasileiro se lançava no progresso e manifestava mais ou menos que uma época de renovação era chegada, o gênio lusitano se obstinava em retrogradar". (p. 22).

Por último, oferece Nunes Ribeiro, confirmando o seu pensamento acêrca da existência da literatura brasileira desde os primeiros tempos da colônia, a sua periodização.

Com louvável sentido de uma filosofia periodológica, afirma que nas dıvisões até então propostas "não se atendeu às evoluções íntimas da literatura, nem ao princípio que as determinava, mas tão sòmente aos fastos e épocas da história política. (p. 23). É perfeita essa afirmativa, e com ela Nunes Ribeiro antecipa-se aos que, em nossos dias, se rebelam contra a periodização de sentido puramente político, em favor de uma divisão inspirada em sentido estético ou literário, isto é, na própria natureza e finalidade da literatura e nas leis internas que presidem à sua evolução. ${ }^{5}$

A divisão que oferece da história literária do Brasil é em três períodos: r) Desde o descobrimento até o meado do século xvir; 2) De Cláudio Manuel da Costa até 1830 ; 3) Dos padres Caldas e S. Carlos,

5 Ver, a respeito, o que disse em meus trabalhos: Introdução à Literatura no Brasil o Conceito de Literatura Brasileira. 
e de José Bonifácio para a época em que escreve (1843). A primeira época é representada por Botelho de Oliveira, com a influência da literatura espanhola; a segunda é representada por Silva Alvarenga, e a influência é da literatura francesa; a terceira tem em Gonçalves de Magalhães o seu representante mais natural e legítimo.

A posição assumida por Santiago Nunes Ribeiro, na Minerva Brasiliense, provocou reações em 'vários periódicos. No Jornal do Comércio, na Sentinela, no Brasil, o artigo sôbre a nacionalidade da literatura brasileira provocou réplicas, a que o próprio autor retruca em artigo posterior. ${ }^{6}$

Novos argumentos e comprovantes são opostos aos contendores, cujas palavras, a seu ver, nem de leve põem em cheque as suas asserçōes.

Afirma um dos opositores que "a literatura está de tal sorte ligada com a linguagem e a religião, que enquanto êsses objetos não forem diversos, não se poderá bem distinguir uma da outra (a portuguêsa da brasileira)". Ao que responde:

E não sabe o autor que a França, a Espanha e Portugal têm a mesma religião, e todavia possuem literaturas diferentes? No que diz da linguagem, o Arquivista nem ao menos se dá ao trabalho de exprimir-se com precisão e propriedade, como o nosso caso o pede; linguaguem não é o mesmo que língua no sentido estrito; é desta última que o autor quis falar; mas, ainda que perdoado seja desta culpa, não pode sê-lo da cometida no sofisma que empregou. (P. II2).

Insiste, contra a opinião de Abreu e Lima, em que "Portugal tem uma literatura nacional, bela e rica em certos gêneros, que o Brasil tem a sua ainda mais notável, atendendo à recente data do ciclo literário êste país".

E retruca a opinião do antagonista, reiterando a sua tese de que a diferenciação brasileira deu lugar a uma literatura própria.

A literatura é a expressão da índole, do caráter, da inteligência social de um povo, ou de uma época: ora o Brasil tem uma índole, um caráter, uma inteligência social própria; logo tem uma literatura própria, isto é, uma literatura brasileira. (p. II3).

6 "Da Nacionalidade da Literatura Brasileira", Minerva Brasiliense, Rio de Janeiro, 1843, vol. I, n. 2, pp. 111-115. 
Ademais, havia as influências exteriores de ordem geográfica. Dizia o seu contraditor: "O Brasil era colônia portuguêsa formada de portuguêses que para aqui transportaram seus penates, com a mesma religião, debaixo das mesmas leis". Ao que responde:

Mas que importa que existissem tôdas essas causas que tendiam a identificar as literaturas dos dois países, se o clima, as inspirações e os novos hábitos que êle trazia deviam necessàriamente influir nos brasileiros? (p. II3).

Assim, por todos os motivos, uma literatura tinha que nascer no país novo, e são postas em relêvo "as diferenças que notamos nas duas literaturas", para provar que "êste país devia inspirar uma nova poesia, e que efetivamente a inspirou". Não seria o fato de o Brasil ser colônia portuguêsa, com a mesma religião, costumes, leis, que "não devia sentir a influência do clima que tudo modifica mais ou menos". Relembra a opinião de Garrett e Ferdinand Denis, para os quais "era possivel que o clima do Brasil inspirasse uma poesia particular e diversa da portuguêsa no seu colorido e fôtça", e mais que era lamentável "que os poetas brasileirós não fôssem mais nacionais, não enriquecessem as suas produções com a poesia especial que êste clima respira". Essa influência que devia exercer a religião, a educação, e as demais causas que tendiam a identificá-las com a poesia portuguêsa".

Quanto a Nunes Ribeiro, seu objetivo é "determinar exatamente a parte que estas causas deviam ter na produção da arte brasileira". (p. Ir4). Pensa que as influências não são anuladas umas pelas outras. Não julga as influências climáticas absolutas.

Os que parecem entender que as inspirações do clima deviam ser tudo, são o Sr. Garrett e alguns ilustres bransileiros cujas opiniões combatemos no já citado artigo, e que increpavam aos poetas seus patrícios por não terem sacudido o jugo da tradição. Não tentamos demonstrar que thes não era dado substrairem-se ao poder do seu século, e com diversas considerações filosóficas procuramos apreciar devidamente o jôgo dessas influências encontradas. Colocando-nos num juste milieu, fomos ecléticos, porque não concedemos tudo ao império da religião costumes e tradições, que a população brasílica recebera de Portugal. (p. II4).

$\mathrm{E}$, de fato, ao exame das amostras da poesia brasileira, o aspecto peculiar surge inconteste. "Se nós fizéssemos a apreciação metódica de 
algumas poesias brasileiras, poderíamos apontar os muitos toques nacionais que a distinguem de envolta com as formas comuns a tôdas as literaturas, e as mais especiais das européias". ( $\mathrm{p} . \mathrm{II}_{4}$ ). Cita poemas do padre Caldas, Durão, Pôrto Alegre, Magalhães, Paranaguá, nos quais "as duas influências ali se encontram e contrabalançam".

No exame das poesias brasileiras cumpre não ver sòmente a exterioridade da arte, que muitas vêzes apresenta as formas gregas e romanas; cumpre atender ao sentido oculto, ̀̀ intimidade, ou pelo menos ao elemento da poesia tradicional que nela se acha combinado ao elemento americano. (p. IIs).

E a doutrina absolutamente certa, mais tarde defendida por Machado de Assis, ao referir, em seu ensaio sôbre o "instinto de nacionalidade", àquele sentimento íntimo que deve ser a nota distintiva de uma literatura.

Corroborando-a ou alicerçando-a, foi inserido na Minerva Brasiliense, em número posterior, um extrato do discurso de Mennechet, lido no Congresso histórico reunido em Paris em r843, sôbre e nacionalidade em literatura. Essa publicação foi promovida por Januário da Cunha Barbosa, o que prova sua concordância com as idéias defendidas pela Minerva e seu diretor. Oferecemos a seguir alguns trechos do referido discurso:

A literatura é nacional quando está em harmonia perfeita com a natureza e clima do país e ao mesmo tempo com a religião, costumes, leis e história do povo que o habita. A natureza é o primeiro espetáculo que se oferece ao homem à sua entrada na vida; o clima é a primeira sensação que êle experimenta; a religião, depois das afeições de familia, é o primeiro amor que se the dá; os costumes formam o primeiro laço social o liga a seus concidadãos, as leis são o primeiro jugo a que é forçado a submeter-se; a história é a primeira glória de que pode ufanar-se. Onde pois o poeta que quer ser nacional irá procurar suas inspirações, a não ser no que vê, no que sente, no que crê, no que sofre, no que ama e no que espera? (p. 168).

Sabemos que há uma poesia independente dos tempos e dos lugares, poesia que não pertence a algum século, a algum país em particular, e sim a todos os países e a todos os séculos: esta é a poesia dos sentimentos, a poesia das paixões, a poesia dos corações. (...) Mas esta poesia universal, que vive em nós, e que bastaria só por si para atestar a nossa comum origem; esta poesia 
que estabelece entre os homens uma fraternidade constante e absoluta, modifica-se ainda assim pela expressão, sob a influência de causas diversas que obram nela; e estas causas são precisamente o que dá à poesia um caráter nacional que a distingue e a faz reconhecer como pertencente antes a um país do que a outro. (p. I69). (...) O culto, quaisquer que sejam a sua extravagância e absurdo, será pois um dos primeiros elementos de sua poesia; êle se fará logo poeta nacional pela religião, afim de o ser depois pelos costumes, pois que sabe que a religião impera nos costumes (...)

Põe em destaque a influência dos costumes, usos e hábitos, "que são nos povos, assim como nos homens, uma segunda natureza, uma segunda existência", e o poeta "será nacional pelos costumes, da mesma sorte que o é pelas crenças". "Como pois the será possível não o ser pelas leis?" $O$ poeta não pode fugir à ação das leis, entendidas estas como "o todo das instituiçōes: ou mais claro, o govêrno do país". Por último, "uma influência há todavia mais poderosa do que as leis, sôbre o gênio de um poeta que quer ser nacional: esta é a da história". (p. 169).

Terminando, após discorrer sôbre o papel da história, afirma haver suficientemente demonstrado que

a natureza e o clima de um pais, a religião, os costumes, as leis, e a história dos povos que o habitam, têm uma influência constante e absoluta sôbre sua literatura; e que a literatura é nacional quando está em harmonia com a história, com as leis, com os costumes, com a religião, com o clima e com a natureza do país em que nascera. (p. I72).

\section{Joaquim Norberto de Sousa e Silva (I820-1891).}

A polêmica sôbre a nacionalidade da literatura brasileira, iniciada por Santiago Nunes Ribeiro na Minerva Brasiliense, veio a ter repercussão anos mais tarde nos trabalhos de Joaquim Norberto de Sousa e Silva, estampados na Revista Popular e outros periódicos da época.

Merece registro, sem dúvida, a valiosa contribuição de Norberto à literatura brasileira, seja no domínio da criação, poesia e romance," seja no da erudição, crítica e história. Além do enorme acervo de trabalhos de pesquisa biográfica, histórica, literária, o que deve ser acentuado sobretudo é a sua contribuição à caracterização da literatura brasileira, sua 
qualificação nacional, sua defesa como literatura própria, numa época em que isso não estava ainda admitido, ao contrário era contestado. Desde o início, colocou-se êle a favor da tese brasileira, procurando demonstrar a natureza original da literatura de seu país.

Seus trabalhos nesta última publicação, tem-se notícia de um seu projeto de história da literatura brasileira, que não chegou a ser reunida em livro, mas cujos primeiros capítulos apareceram na Revista Popular, obedecendo ao seguinte plano, conforme aquela nota: ${ }^{7}$

Livro I. Introdução bistórica. Com os seguintes capítulos:

I. Da Introdução (Tomo 4, p. 357; tomo 5, P. 21).

2. Da Nacionalidade (T. 6, p. 298; t. 7, pp. 105, 153, 201, 286).

3. Da Inspiração (T. 16, pp. 26r, 344).

4. Da Originalidade (T. 9 pp. I60, 193).

Livto II. Século I (1500). Com os seguintes capítulos:

I. Da tendência dos selvagens para a poesia (T. 2, p. $243 ; t$. 3 , p. 5 ; t. 4, p. 27 r).

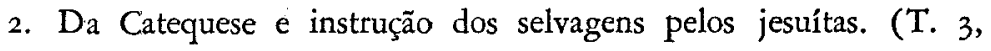
p. 287).

3. Da língua portuguêsa. Inédito.

4. Da literatura portuguesa. Inédito.

Livro III. Século 2 (1600). Inédito.

Livro IV. Século 3 (1700). Inédito.

Livro V. Século 4 (1800). Inédito.

Além dos trabalhos indicados, que constituíriam os capítulos de sua história, devem ser referidos outros que os completam, referentemente ao assunto. 8

Joaquim Norberto, vinte anos depois da polêmica entre Nunes Ribeiro e Gama e Castro, vai nas águas do primeiro, defendendo e afirmando a nacionalidade da literatura brasileira em têrmos bem claros.

A partir do que êle chama "a proverbial propensão dos brasileiros às letras, é levado à afirmativa de que, dentre os povos americanos, o brasileiro "foi também o primeiro a ensaiar-se nos diversos ramos da literatura" ("Introdução Histórica", p. 357):

7 Revista Popular, Rio de Janeiro, 1862. T. 16, p. 261.

8 "Consideraçóes sôbre a literatura brasileira", Minerva Brasiliense, Rio de Janeiro, 1843, 1, pp. 414-417.

"Estudos sôbre a Literatura brasileira durante o século XVII", Minerva Brasiliense, Rio de Janeiro, 1843, I, 1, pp. 41-45 e 2, pp. 76-82.

"Da inspiração que oferece a natureza do nôvo mundo a seus poetas, principalmente o Brasil", Revista do Instituto Histórico e Geográfico Brasileiro, tomo 16 , pp. 261 e 344. 
Ainda não éramos nação mas uma colônia vexada pelo cativeiro, cuja instrução pobre e mesquinha à falta de livros e de escolas e seminários, conquanto não fôsse um delito, era contudo um pesadêlo para a mãe-pátria; ainda não éramos nação, e já tínbamos bistoriadores que namorassem a glória da pátria, poetas que celebrassem a vitória de seus compatriolas, e oradores que do alto da tribuna sagradat, bonram a nossa bistória. Assim engrandecia-se um povo ainda no berço; novo Hércules, que nascia no meio das batalhas, que arrancava em brado heróico e mandava o sinal de sua existência aos povos do Universo, dando eterno assunto aos cantos da poesia; assim a instrução, como um incêndio surdo, ia lenta e densamente lavrando, e quando o seu clarão desabroxou iluminando êsse amplo espaço - grande como os rios, que o limitam ao sul e ao norte- largo como o Oceano que se estende ante êle até aos Andes, que se elevam na parte ocidental, - e quando um brado enérgico $e$ vivificador retumbou do Ipiranga às fronteiras do novo império americano, libertando um povo oprimido, e proclamando a progenição de uma nova e poderosa nação, nós já o éramos pela nossa literatura! Poetas, oradores sagrados, historiadores, músicos, pintores de uma reputação, que nos faz honra, já haviam dado o sinal de nossa cxistência. E pois se é impossível falar no Brasil, sem que se recorde tudo quanto a natureza tem mais belo, mais fecundo, mais precioso, como diz Freycinet; se é impossível falat dêste país, sem que se observe que o ouro e os diamantes saem de seu seio, ao mesmo tempo, que nele prosperam tôdas as culturas, como confessa Beauchamp; é também impossível, falar dos brasileiros como pondera o Sr. Eugène de Morglave, sem que se recorde que são êles os úmicos povos da América, que possuem a sua literatura nacional. (pp. 357358) (Os grifos são nossos).

A longa transcrição, como outras aqui feitas, justifica-se plenamente, não só por ser pouco conhecido o texto, senão sobretudo pela sua importância. É evidente que ela é o resultado da evolução da teoria crítica sôbre o palpitante tema, através dos vários escritores brasileiros que pensaram o assunto, Gonçalves de Magalhães, Nunes Ribeiro e outros.

Mas, em nenhum dêles talvez o pensamento está tão claro e cora. josamente formulado, de uma parte reconhecendo a nacionalidade da literatura brasileira, e de outra a sua existência antes da Independência 
política. E a primeira grande afirmação da desidentificação da nacionalidade literária e da nacionalidade política.

À altura em que escreve (1859), o conceito de literatura brasileira estava completamente fixado, já devidamente esclarecido o problema da nacionalidade literária e da origem da literatura brasileira.

No esfôrço histórico de Norberto, "mencionando os autores, que mais se distinguiram e analisando as suas produçōes" (p. 22), não escapa a menor valia dos escritores dos primeiros séculos:

E certo, que a maior parte dos autores das primeiras épocas, se fazem pouco dignos de comparecer ante o tribunal da posteridade, todavia êles não devem ser excluídos, e ficar como que sepultados no esquecimento. Como nota o Sr. Ferdinand Denis, são êles uma prova evidente da tendência, que de há muito apresentava a nação brasileira para o cultivo das belas artes; como ajunta o Sr. Magalhães, sempre lbes cabe o mérito de servirem de ponto de partida da nossa literatura, e de haverem dado o sinal da inteligência de um pora; (...) patenteavam em suas obras, embora, não fossem primores, uma literatura cujo horizonte ia dilatando todos os dias. (p. 22) (o grifo é nosso).

Ao tratar do problema da periodização, Norberto volta a fazer iniciar a literatura brasileira nos primeiros séculos. Divide a história literária brasileira em seis épocas, sendo a primeira a que "abrange os dois primeiros séculos, isto é, desde o descobrimento do Brasil até fins do décimo sétimo século, e compreende a missão dos jesuítas e seus serviços na propagação das luzes no século décimo sexto, e os poetas e prosadores do século décimo sétimo, dominados pelos desvarios de Gôngora e Marini".

Segue-se, na sua divisão, a seguna época estendendo-se "do comêço até meado do século décimo oitavo, em que ainda dominam o gongorismo e marinismo, mas já bruxoleiam os raios de uma nova aurora, de uma nova tendência para uma poesia mais nacional e menos abastardada". Na terceira, abrangendo a segunda metade do século XVIII, "as tendências para a poesia nacional se desenvolvem". (p. 24).

Como se vê, e nunca é demais salientar a importância do pensamento crítico de Norberto, as letras brasileiras já eram "nacionais" antes da Independência politica, muito embora êsse caráter se viesse desenvolvendo e crescendo com o tempo.

Essa evolução nacional, consoante sua afirmativa, realiza-se também com o 
progresso das letras, do gôsto e das tendências para uma literatura em mais harmonia com os nossos costumes, com os nossos usos, com as nossas crenças políticas ou religiosas e mais digna de uma nação jovem e bela no meio das florestas do novo mundo, sob o céu fulgurante dos trópicos, rodeada de inspirações novas, ardentes e profundas". (pp. 24-25).

Dá o merecido relêvo à literatura dos jesuítas, embora não fôsse, em seu tempo, bem conhecida, obras dramáticas sobretudo, quando "vemos o teatro passar do interior das igrejas para os seus adros, como um meio civilizador" (p. 26), revelando uma compreensão segura do sentido do teatro jesuítico, de finalidade catequética.

Examina, em seguida, a produção cultista e conceptista de influéncia italo-espanhola, as academias, quando a queda para o cultivo das letras se patenteia com a leitura do poema "Brasília", em uma das sessōes da Academia dos Esquecidos, no próprio palácio do governador, "é a prova mais evidente das tendências dos espíritos para as cousas da pátria". (p. 27).

E a transição para a fase "em que a musa americana tem de aparecer com suas inspirações sublimes" (p. 27), na qual Silva Alvarenga levanta a voz contra os poetas "que tão pouco nacionais se mostravam", e quando se sucedem Cláudio Manuel da Costa, Santa Rita Durão, Basílio da Gama e outros, com poemas já verdadeiramente brasileiros. (p. 27). Em seu trabalho sôbre a "nacionalidade da literatura brasileira", de I860, Joaquim Norberto fêz um retrospecto e resumo da polêmica travada na década de 1840 , tirando dela conclusôes adequadas em favor da tese da nacionalidade literária do Brasil. Pelo seu ensaio, fica-se com uma notícia da enorme repercussão do debate na imprensa brasileira, e, mais tarde, na hispano-americana, já que o problema tanto interessava a um como aos outros povos de América.

Eis o sumário do ensaio de Norberto:

Questão suscitada de não possuir o Brasil literatura por pertenecerem as produçôes dos autores brasileiros a Portugal, em virtude dos vínculos, que uniam os dois povos e a identidade da lingua. História dos debates, que se produziram pro ou contra. Triunfo da causa americana. Novas consideraçôes sôbre o absurdo da argumentação dos que pretenderam negar uma tal nacionalidade. (p. 298).

Vê-se, portanto, que Norberto se coloca a favor da tese brasileira, considerando "absurda" a negação da nacionalidade da literatura de seu 
país. Para demonstrá-1o; aduzindo novos argumentos, traça um histórico do debate.

Para êle, "a nacionalidade da literatura de qualquer povo demonstrase por si mesma como a expresão de sua inteligência", e acrescenta:

$\vec{E}$ ela quem patenteia o espírito e a tendência de suas diversas? fases, marchando em progresso ou decadência, segundo as modi'ficações de seus costumes, de seus usos, de suas leis e de seu caráter. Negar essa nacionalidade por haver outro povo, que fala idêntica língua, e em virtude dos vínculos, que uniam os dous povos, é condená-lo à condição de escravo, que ainda depois de liberto tem por destino produzir em benefício de outrém. (p. 298).

Julga que os povos americanos "não poderão sancionar com o silêncio o plágio de tôda a literatura", a quanto equivale o que se pretendeu fazer em relação à produção literária do Brasil. Por isso, a reação da imprensa brasileira, que teve imediato eco em tôda a América e mesmo na Europa "a nosso favor", do que resultou que "a independência política não triunfou tạo majestosamente como a causa da nacionalidade das literaturas da América", "cuja existência se pretendeu negar com tôda a impavidez do pedantismo". (pp. 298-299).

Absurdo pois seria querer-ou que os americanos oriundos dos europeus tivesssem língua própria para poderem possuir uma literatura nacional, - ou então que as suas obras escritas nas línguas de suas antigas mães pátrias pertencessem às literaturas das velhas metrópoles. (p. 299).

Procede, então, Norberto ao relato da polêmica. Expôe e comenta as teses de Abreu e Lima, Gama e Castro e Nunes Ribeiro. Por êle, sabe-se que houve uma tríplica de Gama e Castro, na qual o polígrafo luso cai em contradição, ao ser repelido em seus argumentos.

Insiste Gama e Castro na tese da divisão das literaturas segundo as línguas em que as obras foram escritas, mas, por outro lado, admite que "em uma literatura transluz o gênio da época ou do povo, que a cultiva", e que "considerando na totalidade dos escritos de uma língua a maneira, por que cada um dêles impressiona, o gênio particular que os caracteriza, poderemos algumas vêzes acompanhar um certo númeto de obras debaixo de uma denominação especial; e é neste 
aspecto particular que consideramos os escritos de um país ou de uma nação em separado dos de outra, que cultiva a mesma língua". (p. I09).

Norberto salienta a contradição ou o recuo do articulista português, tão taxativo no primeiro trabalho no negar a nacionalidade da literatura brasileira, que agora aceita.

Outros contendores houve, entre os quais a figura de Januário da Cunha Barbosa, cujo prestígio intelectual se somou aos demais, apoiando a tese brasileira, ao inserir na Minerva Brasiliense o discurso de Mennechet, já referido acima, com uma ligeira nota de apresentação "para servir na presente ocasião de esclarecimento à questáo suscitada", pois dela "muitos literatos se ocupam sem contudo assentarem as verdadeiras bases de uma satisfatória definição". (p. Iro).

Aos brasileiros vieram juntar-se alguns hispano-americanos, como Juan María Gutiérrez, escritor argentino, para quem tampouco "nem sempre pelas línguas se podem classificar as literaturas", e "a fisionomia de um povo proveio de suas instituições". (p. 110).

Increpa Norberto alguns dos contendores por confundirem "a nacionalidade da literatura brasileira com a originalidade das obras de seus autores" (p. III) e ao General Abreu e Lima por não ver "nas obras de seus compatriotas os fundamentos de uma nova literatura que se desenvolve a olhos vistos". (P. III).

como se o espírito de cualquer nação se manifestasse pelos livros produzidos por outra e se pudesse julgar do grau da sua inteligência nas principais épocas de sua existência, estudando-o nas obras elaboradas a duas mil léguas de distância, por autores inspirados por outro céu que não o nosso, escrevendo debaixo de outras influências e dominados or interêsses locais de um reino de todo em todo estranhos ao engradecimento e prosperidade de um grande império. (p. II 2).

O próprio Abreu e Lima, revela Norberto, naturalmente forçado pelo debate, modificou o pensamento em livro posterior, o Compêrndio da História do Brasil ( 1843 ), em cujo prefácio reconhece que "tínhamos uma literatura e que era tempo de começá-la a enriquecer", "preparando os elementos de uma literatura pròpriamente brasileira". (p. II2).

Também a Gama e Castro revida Norberto, afirmando, quianto ao problema do idioma, que 
a identidade da língua entre dois povos não poderá jamais pôr em dúvida a nacionalidade de suas literaturas, pois que não são as literaturas a representação ou símbolo das línguas, mas sim a expressão, a voz da inteligência de qualquer povo, o testemunho de suas inspirações o espêlho de suas tendências, o representante do espírito de suas diversas épocas, quer marche em progresso, quer em decadência, de acôrdo com os seus costumes, com os seus usos, provenientes de seu caráter, de suas leis, e de sua religião. (p. 155).

Para Norberto, a identidade da língua pode quando muito reunir as duas literaturas em uma só expressão - "literaturas da língua portuguêsa" - já que a identidade da língua não pode "pôr em dúvida a nacionalidade de suas literaturas". (p. I55).

Existe a literatura brasileira, cujos autores são pernambucanos, baianos, riograndenses, etc., e se Portugal estivesse ao lado do império situado sôbre o nôvo hemisfério, e houvesse um mesmo nome para designar os dous povos, então não existiriam literatos pernambucanos, baianos ou riograndenses, mas sim brasileiros e portuguêses, pertencentes a uma literatura, que nem seria brasileira nem portuguêsa, mas sob uma denominação que as compreendesse sem exclusão aparente.

Se Portugal não possuísse mais do que a língua que foi transmitida nos dois povos, que persistem agora pelos mesmos ascendentes, e nos formássemos a literatura que vamos formando, poderia só pela identidade da língua reclamar-se que esta se chamasse portuguêsa? Poderia Portugal reclamar ainda para si as produlções de nossos autores, e ocupar por amor delas um lugar entre os povos dados à cultura das letras? Se os Tupis escrevessem em sua harmoniosa língua, se nos transmitissem por meio das letras os seus cantos tradicionais, as suas endeixas de amor, os seus hinos guerreiros, e constituíssem assim uma literatura, seria ela porventura então a literatura brasileira? E ainda mesmo que escrevêssemos na língua dos antigos possuidores do Brasil, seria ela a nossa literatura nacional, e estaria em harmonia com a língua da nação? (Pp. r56-I57).

Novos argumentos são assim aduzidos por Norberto em favor da diferenciação literária brasileira, não obstante a identidade de língua, não hesitando mesmo o crítico em aceitar a designação de brasileira para a 
língua falada por seus compatriotas (p. 157), língua que é dos brasileiros "por um direito hereditário", diferenciada pela influência do clima e caráter dos nacionais e enriquecida pela introdução e numerosos vocábulos diferentes.

Julga irrisório e pedantesco pretender um autor lugar na literatura de um país pelo simples fato de escrever na língua dêsse país, pois nesse caso "o que quizesse merecer um lugar entre tôdas as literaturas escreveria em tôdas as línguas e então veríamos um autor ufanar-se com pertencer a muitas literaturas e muitas literaturas ocupadas com um só autor". (p. 158 ).

Outro contendor, em artigo sôbre "algumas reflexões sôbre a nacionalidade da literatura brasileira" a que Norberto responde sem indicar o local da publicação, e que não foi possivel identificar, concorre para a discussão com outros argumentos.

Diz êle, em primeiro lugar, que "os povos que falam o mesmo idioma, quer afastados ou limítrofes, confundem as suas inspirações num pensamento idêntico, e são conhecidos no mundo das artes por um só nome de família". Ora, retruca Norberto, não é da identidade da língua, não é das inspirações do idioma, que nascem pensamentos idênticos, mas "dos objetos externos expostos à imaginação". (p. I60). Isso é o que ocorre com os indivíduos de uma mesma nação, e não atua entre dois povos, pois entre êles existem condições que geram diferenças de pensar.

A inteligência de um povo, a fisionomia particular do seu país, suas instituições nascidas de suas leis, seus usos, e seus costumes nascidos de sua religião e de seu caráter, não influirão poderosamente sôbre o seu pensamento? A língua não é mais do que um instrumento de que se serve o pensamento para traduzir, para materializar as suas inspirações. (p. 160).

A segunda proposição é de que "o Brasil, colônia portuguêsa, formado de portuguêses, que para aqui transportavam os seus penates, não podia ter tomado anteriormente à sua independência uma índole, um caráter, uma inteligência social acima da de Portugal". (p. I60). Mesmo em relação ao primeito século, em que poderia admitir-se a tese, deve reconhocer-se que os portugueses, ao transplantar-se para a colônia abandonavam obrigações para com o monarca, tanto mais quanto mais se aprofundavam para o interior "onde ninguẻm reconheciam acima de si", e passavam a viver uma existência nova. Nos séculos subseqüentes, "jáessa indole despontava nos nascidos na terra americana; já esse caráter 
ós distinguia dos seus irmãos de além mar, e essa inteligência social lavrava ali e aqui como um incêndio surdo, sem fumo, sem labaredas, sem clarão, aleado em diversos pontos, dirigindo-se para um centro, donde rebentou depois ao Ipiranga..." (p. r6I) Não é possível negar ao povo brasileiro, anteriormente à Independência, uma índole, um caráter; uma inteligência social diversa "não direi acima, mas a par da de Portugal". (p. 16r).

$\mathrm{O}$ argumento mais forte dos defensores da tese lusófila era de que as produçōes intelectuais brasileiras deviam pertencer a Portugal em virtude dos vínculos existentes entre os dois povos.

Ora, é ilusória a crença de que os vínculos políticos dominassem a consciência brasileira de molde a fazếla esquecer os anseios nacionais. Mostra Norberto, em resposta, que foi antiga a diferenciação e especialização da índole psicológica e social brasileira. A história do nativismo mergulha no passado mais longínquo. A rivalidade entre brasileiros e portuguêses sempre existiu no Brasil. Aponta na história fatos e testemunhos eloqüuntes, e cita documentos e opiniões de eruditos para alicerçar o seu ponto de vista. Afirma que os brasileiros levaram vantagem sôbre os portuguêses no interêsse pelo país e se excederam aos lusitanos nas lutas contra os invasores, como no caso dos holandeses, em que D. João IV "ordenava aos brasileiros que depusessem as armas triunfantes", desamparando-os, embora depois que os brasileiros expulsassem os holandeses tornassem "os portuguêses a ocupar o seu lugar".

Por outro lado, continua, não eram os portuguêses os únicos povoadores do Brasil, e o alvará de 1720 , proibindo a emigração portuguêsa para a colônia, é indício de como outros povos concorreram para o povoamento.

O nativismo é fenômeno surgido muito cedo na alma do brasileiro.

Um não sei quê de aferro ao berço natal degenerando em ciume,' fazia com que os brasileiros olhassem com desconfiança para as boas intençôes dos portuguêses, que transportaram os seus penates para júnto de seus lares; e o irmão de além mar era olhado como um hóspede estrangeiro, senão como um inimigo, e muitas vêzes não sem fundada razão. E assim vislumbrava um princípio de nacionalidade, que já extremava dois povos irmãos vivendo no mesmo país, debaixo das mesmas instituições, falando a mesma língua, tendo as mesmas crenças e quase confundindo seus usos e costumes. Desgraçadamente a rivalidade começou logo que apereceram 
os descendentes dos conquistadores, tendo por pátria a terra que lhes descobrira Pedro Álvares Cabral. (p. 20I).

Apoiando-se em textos de Cunha Matos, do Marquês de Lavradio, de Baltasar da Silva Lisboa, de Antônio Rodrigues da Costa, de Monte Alverne, de J. M. Pereira da Silva, de Tomás Jeferson, de Eugène de Monglave, de Paula Meneses, de Gândavo, Botelho de Oliveira, Rocha Pita e outros, Joaquim Norberto faz um histórico do sentimento nativista e da idéia da separação espiritual e social dos dois povos, transparecida em vários episódios do passado da colônia e na reação dos portuguêses ao seu progresso material e intelectual.

Foram freqüentes as ordens régias proibindo os brasileiros de se aplicarem "às ciências e mesmo ãs escolas menores", de possuírem tipografias, de estabelecerem indústrias e fábricas para manufatura do ouro, prata, algodão, lã ou alambique de aguardante.

$O$ descontentamento com o govêrno de Portugal cresceu progressivamente, à medida que se consolidava a consciência do brasileiro contra a situação de inferioridade que lhe era reservada na legislação da Metrópole, situação que dava lugar a constantes atritos entre os brasileiros e os portuguèses vindos para a Colônia investidos de todos os privilégios que thes conferiam uma posição vantajosa na competição social e econômica.

No século XVIIr, afirmam Pereira da Silva e Rodrigues da Costa, citados por Norberto, já se preparava "a separação dos dois reinos" e os habitantes da Colônia já se diziam brasileiros "especializando-se de portuguêses". (p. 204). Não é certo, por tanto, afirmar que não se formava anteriormente à Independência "uma índole, um caráter, uma inteligência social acima da de Portugal", se os homens que aqui viviam "já davam tantos cuidados aos pensadores de além mar", obrigando o govêrno a medidas restritivas e sanções contra os pruridos nacionalistas. Não é justo, acentua Norberto, acreditar que só do grito do Ipiranga "surgiria do nada, como por encanto, um novo povo", pois em verdade "êle marchava com a Metrópole", com a sua inteligência social evoluindo "a par e passo da de Portugal". (p. 204). E cita para comprová-lo os testemunhos de Pero de Magalhães Gândavo e Manuel Boteilho de Oliveira sôbre a existência em seu tempo de "pessoas de engenho e curiosas" como diz o primeiro, tendo o segundo aludido à "existência de uma sociedade, a qual não era estranha à cultura das letras". Também Rocha Pita se refere aos "talentos por eminência grandes" que o Brasil já havia produzido, o que ficou mais tarde confirmado com o estabelecimento da Academia dos Esquecidos na Bahia. 
Prossegue Norberto na demonstração, à luz dos fatos históricos, de que os laços de familia e sangue "nem sempre estreitaram em confraternidade os dois povos", que os vínculos se

não puderam obstar à emancipação política, que de necessidade havia de trazer a efusão de sangue, a perda de grandes vantagens e a adoção de novas instituições, poderiam influir na pacífica separação das duas literaturas, na classificação dos autores, segundo o nascimento de cada um dêles? (p. 287).

E se a própria história não dá razão a essa pretensa união ente os dois povos, como esperar que ela se processe no plano literário? Comenta Norberto essa usurpação:

Orgulha-nos de poder reivindicar para a glória literária da nação portuguêsa as produções da musa brasileira, e não havemos de honrar-nos com têrmos a tantos e tão ilustres autores por nossos compatriotas? Ficaremos condenados a não poder dizer em que século começaram os brasileiros a cultivar as letras, quando mais se avantajaram no seu cultivo, qual dentre êles se tornou mais célebre, e não daremos à narração dessas investigaçōes o nome de história das letras no nosso país, porque as produções de nossos autores pertencem a Portugal?

Não foi bastante que a mãe pátria nos usurpasse o prazer dessa glória durante o longo cativeiro, não de sessenta anos como ela sofreu da Espanha, mas se sessenta lustros? (p. 287).

Refere a seguir a opinião de Januário da Cunha Barbosa, que, no prefácio de seu Parrraso, põe em relêvo a contribuição literária brasileira até aquele momento ( $\mathrm{r} 83 \mathrm{I}$ ), pois, a despeito "de mais de trezentos anos de opressiva tutela", não se pode esconder "o quanto tem sido bafejada e favorecida das musas, particularmente daqueles que, empregando a linguagem das paixões e da imaginação animada, oferecem à admiração das eras exatos modelos do mais delicado engenho e apurado gôsto", e acrescentava que "o conhecimento de patrimônio opulento" que foi a contribuição literária brasileira até então será um estímulo à geração presente.

Refere Norberto que os próprios autores da época colonial que trataram dos escritores daquém e dalém mar, como Rocha Pita, Barbosa Machado, os organizadores das academias, jamais deixaram de consignar a dife- 
rença de nacionalidade entre portuguêses e brasileiros, "não obstante êsses laços de família". (p. 288).

Os próprios autores procuravam extremar-se dos autores nascidos além-mar, declarando as naturalidades no frontispicio de suas obras, presunção a que devemos o não esbulho de muitas produções, que sem ela passariam com outras muitas ao domínio da mãe pátria, que de bom grado se arrogaria a privilégio de sòmente poder produzir obras literárias, monopolizando a literatura como monopolizara a instrução, a imprensa, a indústria e o comércio. (p. 288).

Em conclusão do seu estudo, declara Norberto:

Passe em aresto a questão da nacionalidade da nossa literatura. Para os brasileiros é ela mais que líquida. (p. 289).

E cita Gonçalves Dias, que, no prefácio às Sextilbas de Frei Antão (1848), afirma alto e bom som, como a encerrar o debate:

As literaturas brasileiras e portuguêsa hão de ser duas, mas semelhantes e parecidas, como irmãs, que descendem de um mesmo tronco, e que trajam os mesmos vestidos, embora os trajem por diversa maneira, com diverso gôsto, com outro porte e graça diferente.

Era a nacionalidade da literatura brasileira insofismàvelmente proclamada, ao mesmo tempo que os estrangeiros a reconheciam, como Eugène de Monglave, em comunicação ao Instituto Histórico de França, afiançando que o Brasil era "o único país, que tem na América a sua literatura nacional".

E essa nacionalidade literária não estava na dependếncia da nacionalidade política, como o demostrou tôda a polêmica. Ao contrário do que pensavam os defensores da tese portuguêsa, Garrett, José Feliciano de Castilho, Gama e Castro, a nacionalidade literária prepara a política. E o que afirma Paula Meneses:

Um povo, que não tem uma literatura, chegará difícilmente a ser uma nação, porque a nacionalidade rebenta do sentimento vivo de sua glória passada e das tradiçóes de seus maiores, cujos nomes e 
preciosos trabalhos a literatura, como um eco imortal, repetirá até às mais remotas gerações da terra. (p. 29r).

Iniciada, assim, no início da década de $\mathrm{x} 840$, a polêmica sôbre a origem e nacionalidade da literatura brasileira atingiu o seu têrmo em I860.

O trabalho de Joaquim Norberto consagra a conclusão a favor da tese brasileira. A literatura brasileira teve início desde os primeiros momentos da colonização e se mostrou com características próprias, diferenciadas, originais, desde então, a despeito dos vínculos políticos que ligavam os dois povos, o que quer dizer que a nacionalidade literária independe da política.

No pensamento dos críticos e teóricos literários românticos, eram identificadas as idéias da origem remota da literatura brasileira e da nacionalidade brasileira da literatura desde os primeiros tempos da colonização, através de um processo de diferenciação cedo operado na consciência do homem que começou a povoar o novo mundo.

Resta averiguar como se identificava essa nacionalidade, quais os seus característicos e sinais exteriores, qual o dever e o caminho dos escritores para alcançá-la.

E outro aspecto da questão.

Academia Brasileira

de Letras, Rio. 